\title{
Eksplorasi kreativitas desain melalui konsep upcycle material produk furnitur paska pakai
}

\author{
Tri Noviyanto P Utomo, ${ }^{1 *}$ Yusita Kusumarini, ${ }^{2}$ Stephanus Evert $S^{3}$ \\ ${ }^{1,3}$ Program Studi Interior Arsitektur, Universitas Ciputra, Surabaya, Indonesia \\ ${ }^{2}$ Program Studi Desain Interior, Universitas Kristen Petra, Surabaya, Indonesia
}

\begin{abstract}
The number of post-use or damaged furniture products before their time becomes a problem especially for ecological problems in the work environment. This research tries to eksplore the creativity of product design based on the principles derived from the concept of green design. One of the principles of green design derived is the upcycle concept. Through the upcycle concept approach, this research tries to construct eks office material into an eksplorative and ecological new design. This research uses a case study of eks office / campus furniture products that are no longer in use due to damage. The design model based on upcycle concept and formalistic design is used as a basis for design and to analyze design results. The results of this study in addition to creating eksplorative design products, also eksplain the principles of ecological regenerative design values, namely optimizing the use of waste materials, durability of product life that can be ekstended, as well as supporting environmental protection and increasing product values and aesthetics.
\end{abstract}

Key words: product of upcycle, product regeneration, green design, furniture design

\begin{abstract}
Abstrak
Banyaknya produk furnitur paska pakai atau rusak sebelum waktunya menjadi persoalan tersendiri terutama terhadap permasalahan ekologis di lingkungan kerja. Penelitian ini mencoba mengeksplorasi kreativitas perancangan produk dengan berdasar pada prinsip-prinsip turunan dari konsep green desain. Salah satu prinsip green design yang diturunkan adalah konsep upcycle. Melalui pendekatan konsep upcycle, penelitian ini mencoba mengkonstruksi material eks kantor menjadi desain baru yang eksploratif dan ekologis. Penelitain ini menggunakan studi kasus terhadap produk-produk eks furnitur kantor/kampus yang sudah tidak terpakai lagi karena rusak. Model perancangan berbasis konsep upcycle dan formalistik desain digunakan sebagai dasar perancangan serta untuk menganalisis hasil desain. Hasil penelitian ini di samping menciptakan produk desain yang eksploratif, juga menjelaskan prinsip dari nilai-nilai desain regeneratif yang ekologis yaitu optimalisasi pemanfaatan material limbah, durability umur pakai produk yang bisa diperpanjang, serta ikut mendukung perlindungan terhadap lingkungan dan meningkatkan nilai-nilai maupun estetika produk.
\end{abstract}

Kata kunci: produk upcycle, regenerasi produk, green design, desain produk furnitur

\section{Pendahuluan}

Setiap produk desain yang dibuat akan mempunyai umur pakai tertentu. Adakalanya produk telah rusak atau tidak bisa digunakan lagi meski umur pakainya masih panjang. Produk-produk yang telah memasuki umur pakai sebelum waktunya biasanya akan dijual ke pengepul barang, dibuang atau dimusnahkan. Beberapa diantaranya mungkin dapat direpair kembali dengan mengganti bagian-bagian yang rusak dengan komponen baru. Penggantian komponen yang rusak dengan komponen baru menjadi persoalan jika harga komponen baru pengganti tersebut tidak sebanding dengan harga baru produk. Beberapa komponen yang tidak tersedia lagi di pasaran atau sudah tidak diproduksi lagi, maka produk tersebut masuk dalam masa pembuangan atau penghancuran. Pembuangan dan penghancuran terhadap produk tersebut tentu saja akan menyisakan persoalan lain lagi, terutama yang berkaitan dengan masalah material yang sulit terurai oleh alam secara ekologis. Berbagai upaya mungkin telah dilakukan guna mencari solusi terhadap

\footnotetext{
* Corresponding author Tel: +62-031-745-1699; fax +62-031-745-1698; e-mail: tommy@ciputra.ac.id
} 
permasalahan ini, diantaranya adalah menciptakan kembali siklus hidup baru bagi produk yang umur pakainya telah lewat. Tujuannya disamping untuk memperpanjang kembali masa pakai produk juga tentu saja untuk membuat produk kembali mempunyai nilai-nilai estetika, ekonomi maupun nilai ekologis yang baru.

Salah satu yang dilakukan dalam menciptakan siklus hidup produk adalah guna mengurangi populasi sampah, khususnya sampah yang tidak mudah terurai secara ekologis. Data yang dihimpun oleh Sustainable Waste Indonesia (SWI) dalam satu dekade ini menunjukkan bahwa tanggung jawab perusahaanperusahaan di Indonesia masih rendah dalam pengelolaan sampah-sampah anorganik. Dalam catatan SWI hanya $10 \%$ sampah plastik yang terdaur ulang, 50\% nya berakhir di tempat pembuangan akhir (TPA) dan sisanya tidak tertangani dengan jelas (Syahni, 2019). J Jambeck dalam salah satu risetnya tentang limbah plastik menyatakan bahwa Indonesia merupakan penghasil sampah plastik terbesar kedua di lautan di bawah Tiongkok, namun bukan berarti menjadi pengguna plastik terbesar kedua di dunia. Masalah terbesar sampah plastik Indonesia adalah persoalan manajemen sampah plastik yang masih rendah. Data riset menyebut bahwa negara Amerika Serikat menggukana plastik rata-rata 38 juta kg/hari, namun negara ini berhasil mengelola sampah plastik hingga angka mismanaged plastic waste hampir tidak ada. Indonesia menggunakan 11 juta $\mathrm{kg} /$ hari namun sampah plastik yang tidak bisa dikelola 9 juta/hari (Jambeck, 2015). Oleh karenanya penting kiranya pengelolaan sampah yang terpadu agar tidak terjadi lagi penumpukan dari sampah yang tidak terurai secara ekologis. Salah satu cara mengatasi persoalan ini adalah dengan menciptakan circular economy (ekonomi sirkular), dimana sampah dikelola dengan menciptakan siklus produksi yang baru dengan mengelola konsumsi dan daur ulang material yang dapat menghasilkan kebaruan nilai-nilai ekonomi (Syahni. D, 2019).

Penelitian ini mencoba menawarkan konsep pendekatan yang ekologis. Pendekatan ekologis dilakukan dengan mengolah perabot dari eks kantor atau kampus yang masa pakainya telah lewat (rusak) dengan material pendukung lainnya yang alami dan yang ketersediaannya mudah diakses oleh masyarakat secara ekonomis. Upaya pendekatan ekonomis secara optimal dilakukan dengan seminimal mungkin tidak mengganti bagian-bagian produk yang rusak dengan yang baru namun dengan mengkonstruksi ulang komponen-komponen yang dapat digunakan kembali. Tujuan penelitian ini adalah upaya untuk memperpanjang umur pakai produk khususnya produk furnitur dan menciptakan nilai-nilai desain baru dari material limbah. Melalui kreativitas olah material dan eksplorasi konstruksi komponenkomponen eks furnitur kantor/kampus diharapkan akan menghasilkan desain baru yang solutif bagi permasalahan ekologis, ekonomis maupun sosial. Studi kasus dalam penelitian ini dilakukan dengan menggunakan eks produk-produk furnitur yang sudah tidak terpakai atau yang memasuki masa pembuangan akhir (disposal) di lingkungan kampus Universitas Ciputra Surabaya.

\section{Pengembangan konsep green design.}

Pengembangan konsep green design khususnya dalam dunia industri berfokus pada usaha untuk mengurangi konsumsi energi dan penggunaan material alam dengan mengoptimalkan prinsip daur ulang serta mengurangi emisi zat-zat berbahaya yang keluar dari proses peroduksi. Konsep inti dari green design ini dikenal dengan prinsip 3R: Reducing, Reusing dan Recycling (Jiang XU \& Ping GU, 2015). Dalam desain industri modern, konsep 3R kemudian mengalami perkembangan guna merinci lebih jauh lagi konsep daur ulang menjadi 4R yaitu Regenerasi dengan menciptakan sesuatu yang baru dari yang ada. Prinsip dari regenerasi (Regeneration) menurut Ruiz Du dalam bukunya "Product Durable Design", ada empat aspek pendukung yaitu: perawatan terhadap permukaan material produk, memperbaiki kekurangan dengan bahan daur ulang namun dengan mempertahankan struktur produk, memanfaatkan fitur-fitur dari bahan sekuder untuk mendesain serta mencoba untuk tidak menambahkan material baru lainnya (Du, 2002). Prinsip 4R ini menjadi lebih bisa menyederhanakan, merampingkan transformasi menjadi lebih baik dan terukur. Prinsip regenarasi juga berusaha memperhatikan siklus energi dalam proses produksinya yang tentu saja tujuan utamanya adalah untuk memperpanjang umur produk daur ulang (Wang \& Su, 2013).

\section{Konsep produk upcycle}

Dalam perspektif konsep upcycle, siklus hidup produk digambarkan sebagai rantai perjalanan produk desain yang dimulai dari pemilihan material, proses produksi, penggunaan oleh konsumen akhir sampai dengan produk mengalami kerusakan dan berakhir di tempat pembuangan. Sebagian komponen produk yang masih bisa digunakan di desain ulang kembali menjadi produk lain. Demikian seterusnya berputar sampai produk mengalami kehancurannya sendiri atau diolah menjadi energi lain. Konsep upcycle juga merupakan salah satu upaya untuk menciptakan produk baru dengan nilai yang lebih tinggi dari 
Tri Noviyanto P Utomo, Yusita Kusumarini, Stephanus Evert S

Eksplorasi kreativitas desain melalui konsep upcycle material produk furnitur paska pakai

sebelumnya melalui penggunaan material yang telah terbuang atau material paska pakai (Myers, 2014).

Kata upcycling pertama kali disebut (secara harfiah) oleh insinyur Jerman yang bernama Reiner Pilz pada tahun 1994 yang dalam keterangannya dikatakan sebagai berikut: "Daur ulang adalah sama artinya dengan down-cycling”, dimana obyek yang telah usang diberikan atau ditambahkan nilai-nilai baru namun tetap menjaga bentuk aslinya semaksimal mungkin (Pilz,1994). Selanjutnya konsep ini dipertegas kembali bahwa pada dasarnya upcycle adalah penggunaan kembali produk daur ulang atau produk yang dibuang dengan mengurangi material baru dan memberinya nilai lebih bukan menjadi lebih sedikit (Sung, 2015). Istilah tersebut kemudian menyebar dengan kecepatan lambat tetapi eksponensial ke sektor industri lainnya seperti mode, daur ulang plastik, sampah organik, otomotif, elektronik, furnitur dll. Gambar 1 memperlihatkan siklus hidup produk upcyle.

\section{Upcycling dan Ekonomi}

Upcycling adalah bagian dari konsep besar dari (Sustainable Delevelopment) atau pembangunan berkelanjutan, yang biasa disebut juga sebagai Circular Economy (CE). Dalam penelitiannya Kirchherr, Reike \& Hekkert "mendefinisikan Circular Economy ini sebagai sistem ekonomi yang menggantikan konsep dari 'akhir kehidupan' yaitu dengan mengurangi, menggunakan kembali, mendaur ulang, dan memulihkan bahan dalam produksi/ distribusi dan proses konsumsi. Pada intinya konsep upcycle memiliki tujuan besar dan holistik, yaitu untuk menciptakan secara simultan terhadap perbaikan kualitas lingkungan, kemakmuran ekonomi dan keadilan sosial, untuk kepentingan generasi sekarang dan masa depan" (Kirchherr, J., Reike, D. and Hekkert, M, 2017).

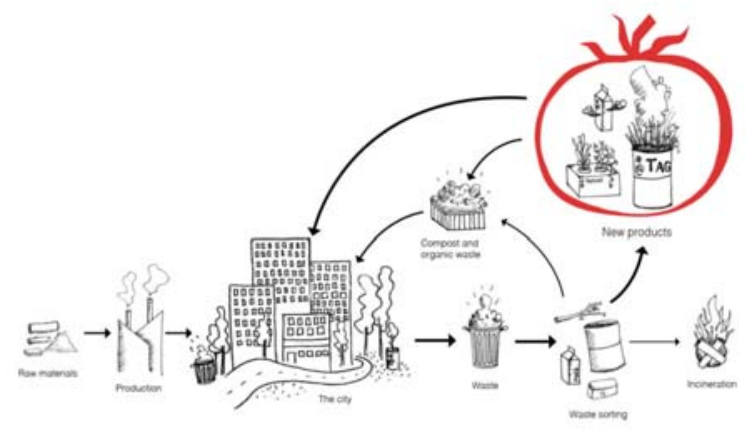

Gambar 1. Siklus Hidup Produk Upcycle (Sumber: Danish Upcycle)

\section{Prinsip Konsep Regenerasi dalam Perancangan produk}

Terdapat lima prinsip mendesain ulang dengan pendekatan konsep regenerasi menurut Jiang XU \& Ping GU. Yang pertama adalah prinsip peningkatan nilai Produk. Sasaran inti dari produk upcycle adalah untuk mempromosikan nilai-nilai material limbah daur ulang dan mengubahnya menjadi produk bernilai baru dalam ekonomi maupun ekologi. Prinsip tersebut menuntut kreativitas para perancang produk dalam menggali nilai-nilai yang potensial dari limbah produk, terutama dalam perspektif fungsi, material, struktur, dan estetika. Yang kedua adalah prinsip pemanfaatan limbah daur ulang secara maksimal. Mendesain ulang limbah produk sebagai bahan baku dilakukan semaksimal mungkin mengurangi bahan sisa yang dihasilkan dari proses produksi serta menghindari limbah sekundernya. Desainer membutuhkan pengetahuan yang luas dan kesadaran akan lingkungan yang baik dalam membuat program yang logis dan terstruktur guna mengontrol, mengarahkan, mengklasifikasi material dan komponen limbah yang akan digunakan. Tidak setiap desain dari material limbah dapat dimanfaatkannya kembali penggunaanya.

Prinsip yang ketigad adalah prinsip durability dan lingkungan. Meskipun bahan baku untuk mendesain ulang produk berasal dari barang bekas, tidak berarti produk tersebut mempunyai kualitas yang buruk. Sebaliknya, para desainer harus memperlakukan material bekas tersebut sama tanpa diskriminasi, dan mengembangkannya dengan status produk reguler yang sama untuk memastikan kualitasnya bisa tahan lama sehingga memperpanjang umur layanannya. Berikutnya adalah prinsip Pengendalian Biaya. Prinsip ini berkaitan dengan pengendalian sumber biaya yang keluar dari proses desain. Proses diesain yang di mulai dengan memilihan material, sampai dengan proses produksi. Jadi pengendalian biaya ini membutuhkan keahlian tertentu dari desainer untuk mempertimbangkan semua poin dari proses desain, sehingga secara efisien dapat mengendalikan biaya dalam proses desain dan mampu menciptakan nilai produk melalui desain yang baru. Prinsip yang terakhir adalah prinsip estetika publik. Selera estetika publik menjadi acuan yang seharusnya dalam prinsip desain produk upcycle ini. Melalui prinsip tersebut desainer dituntut memiliki kualitas visual yang baik, wawasan yang tajam dan terbiasa dengan kondisi permintaan pasar, serta peka dengan elemen modis dan tren yang populer bagi masyarakat. Desainer disarankan untuk tidak mengambil pemikiran dan nilai-nilai idealisme individu yang 
berlebihan ke dalam desain, terlebih menjadikannya sebagai "mainan" pribadi dengan tidak menyesuaikan dengan selera estetika publik.

\section{Metode penelitian}

Penelitian ini menggunakan metode deskriptif kualitatif melalui studi kasus terhadap perancangan produk dengan menggunakan eks material furnitur kantor yang sudah tidak bisa digunakan lagi di lingkungan kampus Universitas Ciputra Surabaya. Model perancangan berbasis konsep upcycle dari green design digunakan untuk menganalisis prinsip perancangan produk yang berbasis material daur ulang. Metode perancangan produk menggunakan tahapan-tahapan atau fase proses seperti yang dikembangkan oleh Ginting (2010), namun dengan penyesuaian produk yang didesain. Fase proses perancangan tersebut adalah: Fase informasi, fase ini berisi pengumpulan data-data awal seperti material yang digunakan, klasifikasi dan kriteria teknis produksi yang menyangkut mekanisme pembuatan dan struktur penetapan fungsi komponen dari produk limbah. Fase kreatif akan menentukan kriteria desain, alternatif desain dan pengembangannya berserta atribut-atribut pendukung desain seperti meminimalisir penggunaan material tambahan yang baru. Fase analisa akan memberikan gambaran tentang desain hasil fase sebelumnya dan analisa penerapan prinsip-prinsip upcycle terhadap produk. Fase Pengembangan desain dan fase presentasi merupakan hasil akhir dari proses perancangan yang berupa desain sebelum memasuki tahapan pembuatan prototype. Secara prinsip fase perancangan tersebut mengacu pada tahapan-tahapan formalistik desain yang digambarkan dalam Gambar 2.

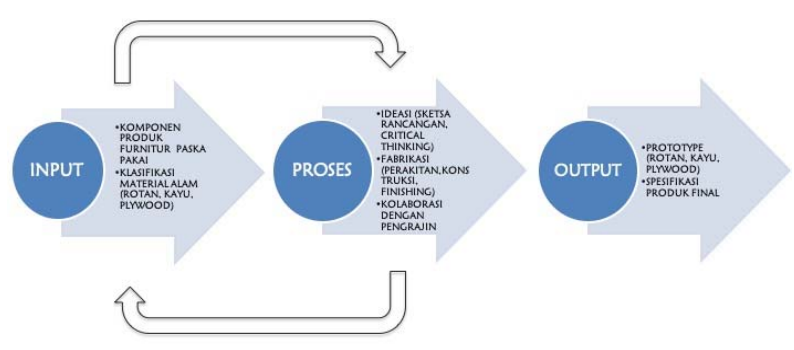

Gambar 2. Bagan Alur Perancangan formalistik produk desain

\section{Hasil dan pembahasan}

Berbasis metode perancangan formalistik dan fase pengembangan dalam perencanaan produk dari Ginting (2010), maka pada tahapan awal ini dimulai dengan:

Fase Informasi adalah tahapan pengumpulan data yang terkait dengan bahan material yang akan dipergunakan. Data bahan material yang akan dipergunakan berasal dari eks furnitur kantor yang biasa dipergunakan di lingkungan kampus namun kondisinya sudah tidak bisa dipakai lagi atau rusak. Furnitur-furnitur tersebut kebanyakan dari kursi kantor maupun kursi kuliah yang materialnya terbuat dari besi dan plastik. Berikut ini adalah furnitur yang diambil dari gudang kampus tempat pengumpulan barang-barang yang sudah tidak terpakai lagi atau rusak, dan menunggu untuk dibuang atau dijual lagi sebagai barang rongsokan oleh pihak luar.

Produk-produk yang rusak tersebut kemudian didata dan dipilih dengan berbagai pertimbangan misalnya dengan melihat kondisi produk yang rusak ringan, sedang sampai rusak berat. Pertimbangan lain adalah faktor biaya yang semaksimal mungkin bisa ditekan dengan memilih material yang komponennya masih bisa dipergunakan lagi.

Data lainnya adalah penggunaan material penunjang perancangan seperti material dari industri kayu olahan seperti plywood dan besi. Material kayu lapis yang digunakan adalah sisa dari buangan limbah pabrik kayu lapis yang berupa potongan dengan berbagai ukuran. Ukuran yang paling lebar bisa mencapai $10-15 \mathrm{~cm}$ dengan panjang bervariasi dari $60-90 / 120 \mathrm{~cm}$. Potongan-potongan kayu lapis tersebut merupakan sisa dari ukuran standar pesanan pasar 122 x $244 \mathrm{~cm}$. Berikut adalah potongan kayu dari sisa produksi yang ditawarkan kepada pihak lain berminat membeli atau dijadian bahan bakar untuk bahan oven kayu. Bahan-bahan yang sudah terdata dan terkumpul tersebut kemudian dipilih dan dipisahkan untuk memudahkan proses selanjutnya yaitu membuat sketsa-sketsa ide dari kombinasi antar komponen materialnya. Berikut digambarkan proses pengolahan data dari eks furnitur kantor paska pakai dan material pendukung desain.

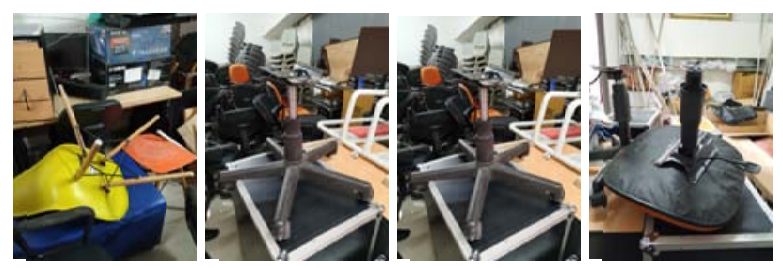

Gambar 3. Produk eks furnitur kantor yang sudah rusak (Dokumentasi pribadi) 
Tri Noviyanto P Utomo, Yusita Kusumarini, Stephanus Evert S

Eksplorasi kreativitas desain melalui konsep upcycle material produk furnitur paska pakai
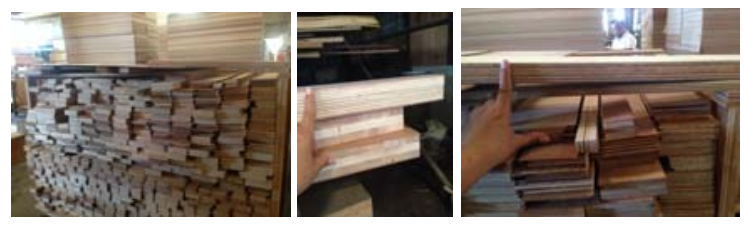

Gambar 4. Potongan Plywood sisa produksi dari industri kayu lapis (Dokumentasi pribadi)

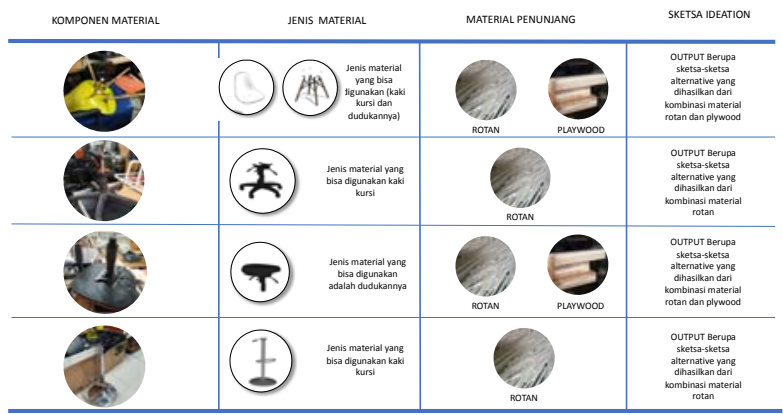

Gambar 5. Klasifikasi pengolahan data. (Dokumentasi pribadi)

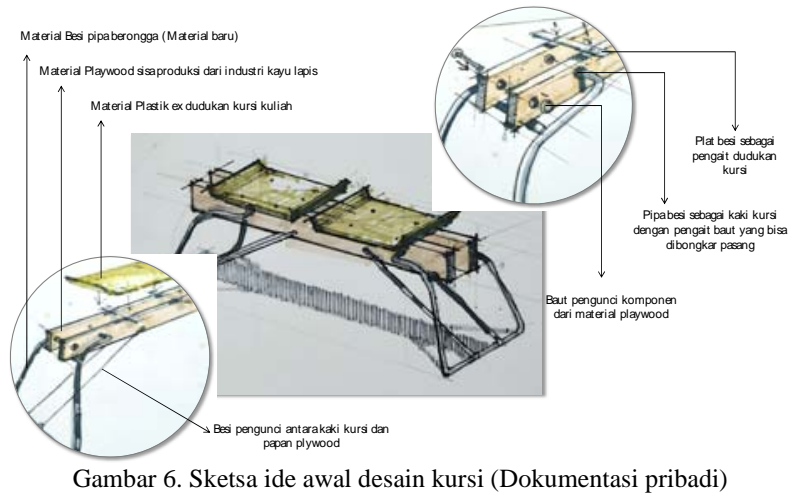

Gambar 6. Sketsa ide awal desain kursi (Dokumentasi pribadi)

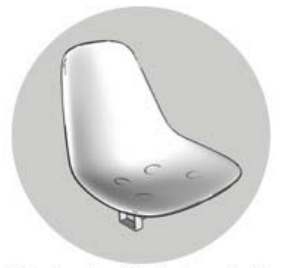

Dudukan kursi berbahan plastik moulding ex furnitur kantor/kuliah

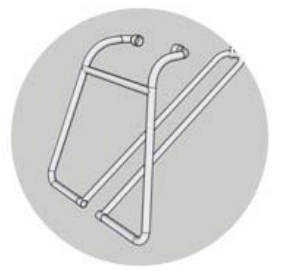

Kaki-kaki kursi dari bahan pipa besi berongga (Material baru)

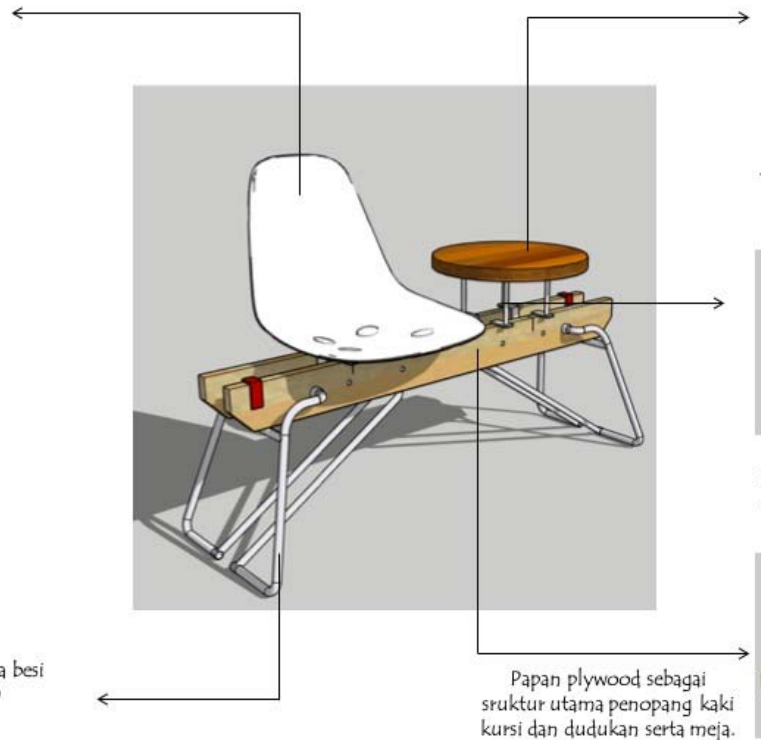

kursi dan dudukan serta

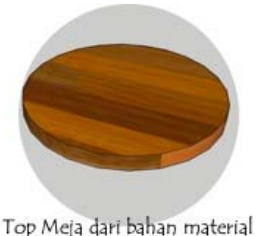

plywood sisa produk

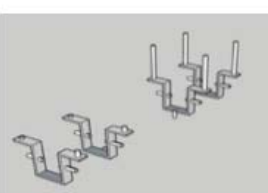

Joint-joint pengait dari plat besi yang dimodifikasi untuk dukukan kursi, top meja dan kaki serta papan plywood

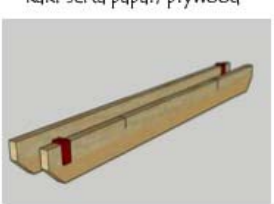

Gambar 7. Sketsa pengembangan desain kursi (Dokumentasi pribadi) 
Sketsa Ideation: Kolom ini akan menggambarkan berbagai alternatif desain yang dihasilkan dari beberapa kombinasi antara komponen utama furnitur dan material penunjangnya. Hasil dari kolom ini berupa gambar sketsa ide dengan deskripsi yang menjelaskan fungsi serta mekanisme penggunaan dari produk yang dirancang. Sketsa-sketsa ini kemudian akan dianalisa dan dipilih dengan kriteria-kriteria tertentu misalnya tingkat kesulitan dalam perakitan, biaya pembuatan yang ekonomis, kemudahan penggunaan, kekuatan serta faktor-faktor yang terkait dengan estetika produk.

Fase Kreatif adalah tahapan dimana bahan-bahan material perancangan yang sudah ditentukan dan diklasifikasikan dalam fase informasi kemudian dibuat sketsa-sketsa ide yang memungkinkan terciptanya desain dan nilai baru. Berikut ini adalah beberapa sketsa desain yang didasarkan pada penggunaan komponen dan material eks furnitur kantor dan material sisa produksi dari industri kayu lapis.

Fase analitik produk merupakan tahapan di mana digambarkan proses dari siklus perjalanan produk mulai awal pembuangan, pemilahan/sortir, supply material pendukung, ide desain sampai tercipta produk baru. Salah satu gambaran siklus konsep upcycle untuk produk eks furnitur kantor diperlihatkan dalam Gambar 9.

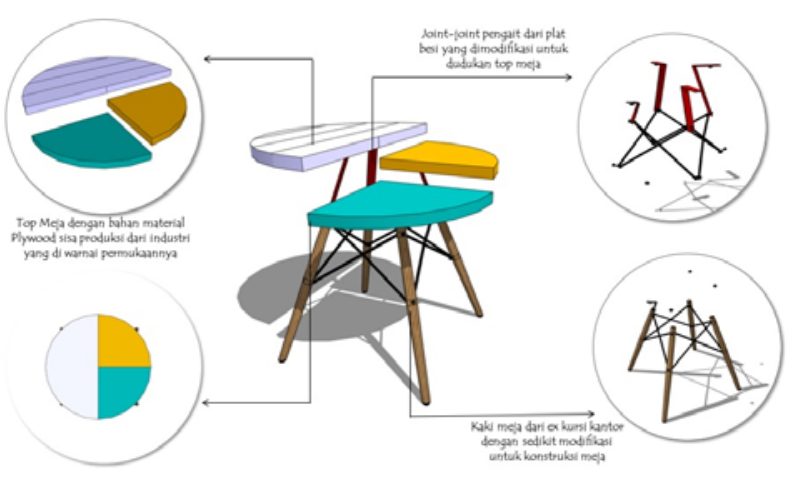

Gambar 8. Sketsa desain meja (Dokumentasi pribadi)

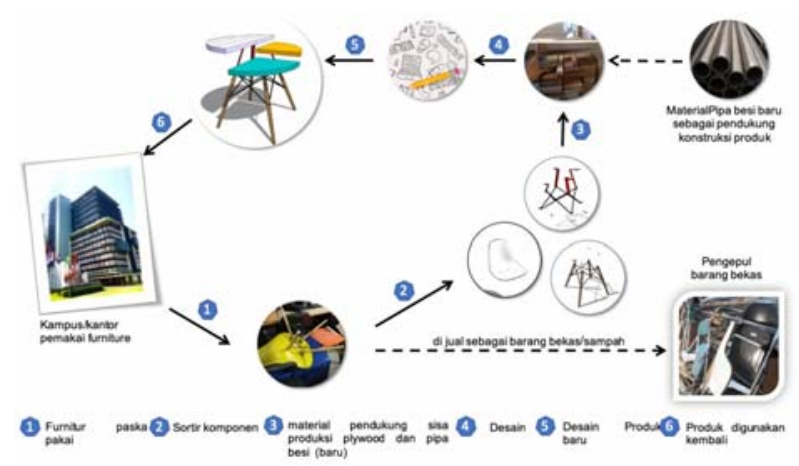

Gambar 9. Salah satu gambaran siklus Produk furnitur Upcycle (Dokumentasi pribadi)

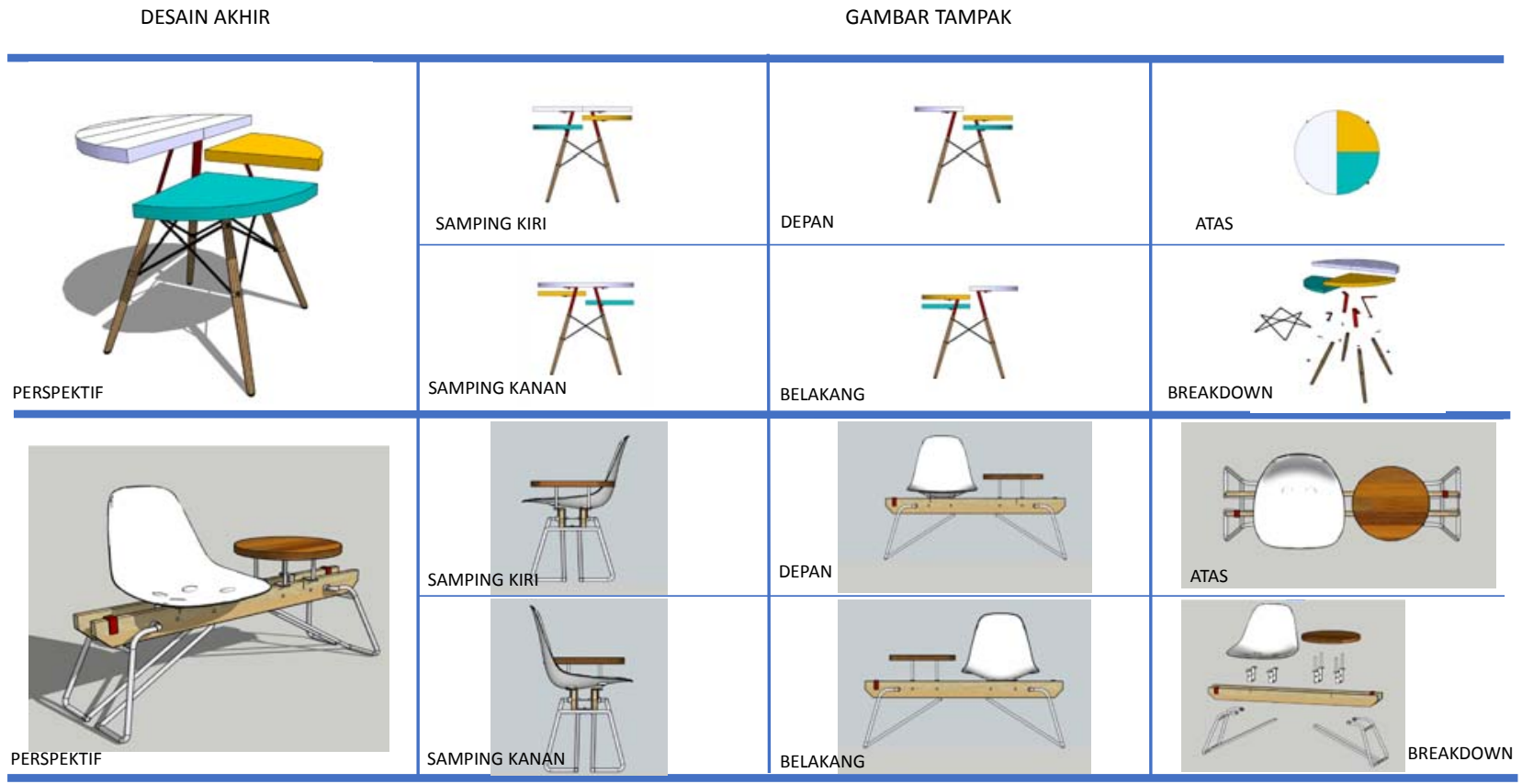

Gambar 10. Desain akhir Produk Upcycle eks furnitur kantor (Dokumentasi pribadi) 
Fase pengembangan dan presentasi desain dalam proses perancangan ini merupakan tahapan untuk melengkapi dan mengevaluasi hasil desain sebelum masuk tahapan produksi. Beberapa alternatif desain dibuat dan kemudian dipilih berdasarkan pertimbangan-pertimbangan tertentu. Gambar 10 memperlihatkan desain yang dipilih untuk dikembangkan dan dipresentasikan serta direkomendasikan sebagai produk untuk diproduksi.

\section{Prinsip Konsep Regenerasi pada Produk eks Furnitur Kantor}

Pendekatan konsep produk regenerasi menurut Jiang XU \& Ping GU (2015), dinyatakan melalui lima prinsipnya yaitu: (1) Penciptaan nilai (values) produk melalui pemanfaatan limbah atau material daur ulang. Dalam kasus perancangan furnitur ini, nilai-nilai desain terlihat melalui pemanfaatan produk dengan penggunaan bahan material eks furnitur kantor yang telah rusak atau tidak bisa digunakan lagi secara maksimal. Seleksi material limbah yang ketat dilakukan dengan tujuan untuk menciptakan produk baru dengan cara mengurangi material baru dan memberinya nilai lebih bukan lebih sedikit (Sung, 2015); (2) Optimalisasi Pemanfaatan limbah. Limbah atau material daur ulang yang digunakan dalam kasus perancangan ini hampir mencapai 80\%, yang diantaranya memakai kembali material lama seperti dudukan kusi atau kaki-kaki meja. Material baru hanya digunakan untuk membuat konstruksi kaki kursi yang membutuhkan komponen yang kuat; (3) Durability dan ramah lingkungan. Faktor ketahanan dan kekuatan produk menjadi perhatian utama disamping tampilan visual. Dalam kasus perancangan furnitur ini prinsip ketahanan dan lingkungngan ditunjukkan dengan pemilihan komponen pemakaian material limbah dilakukan dengan selektif serta dukungan material sisa industri kayu lapis dengan kualitas yang baik serta memiliki sertifikasi ramah lingkungan sebagai bahan sisa ekskspor; (4) Pengendalian biaya. Prinsip dari pengendalian biaya ini adalah semaksimal mungkin ada upaya untuk menekan biaya-biaya yang keluar dari proses produksi yang sulit akibat dari desain yang rumit. Dalam kasus ini biaya yang cukup dominan dapat diperkirakan keluar dari proses pembuatan oleh tenaga produksi, sisanya untuk finishing dan pembelian material baru pendukung konstruksi kaki kursi yang terbuat dari besi; (5) Prinsip Estetika publik. Prinsip ini memerlukan uji publik yaitu dengan menunjukkan kepada masyarakat apakah desain baru yang telah dibuat dengan limbah eks furnitur kantor ini menarik perhatian publik. Penilaian ini menjadi arena evaluasi juga bagi desainer atas produk yang diciptakannya. Dalam kasus perancangan ini uji publik belum bisa dilakkukan secara maksimal karena lingkup bahasan dalam penelitian ini hanya sampai pada tahapan desain, sedangkan implementasi pembuatan produk akan dilakukan dalam penelitian-penelitian selanjutnya.

\section{Kesimpulan}

Mendesain produk daur ulang sesungguhnya tidak mudah untuk dilakukan. Desainer memerlukan pengetahuan serta wawasan yang luas tentang siklus hidup produk, prinsip-prinsip upcycle dan turunannya yaitu konsep regenarasi produk, dan tidak hanya terbatas pada orientasi teknis perancangan semata. Paling tidak desainer perlu menanamkan lima prinsip dari konsep regenarasi produk yaitu : Orientasi penciptaan nilai desain dengan material limbah, Optimaliasi material limbah, Orientasi pada ketahanan produk ramah lingkungan, Pengendalian biaya serta Perhatian pada estetika publik jika akan melakukan perancangan yang berbasis pada material daur ulang atau material limbah.

Saran untuk penelitian-penelitian selanjutnya adalah menciptakan edukasi kepada masyarakat tentang bagaimana konsep produk upcycle diciptakan serta diuji publik, sehungga publik mendapatkan pengetahuan baru terhadap nilai-nilai desain dengan prinsip-prinsip regenaratifnya. Edukasi juga dapat dilakukan dengan menciptakan kolaborasi kerja antara desainer dan para pembuat furnitur (tukang), para pengepul barang bekas serta industri penghasil limbah produk sehingga tercipta ekosistem produksi yang dapat menciptakan nilai-nilai ekonomi, sosial dan budaya baru bagi masyarakat.

\section{Daftar pustaka}

Jiang, XU., \& Ping, GU. (2015). Five Principles of Waste Product Redesignunder the Upcycle Concept. International Forum on Energy, Environment Science and material (IFEESM 2015). Published by Atlantis Press.

Du, R. (2002). Product durable Design. Taipei: The Pacific book publishers.

Kay, T., \& Reiner Pilz. (1994). Salvo NEWS (99), pp 11-14.

Myers. (2014). Designing and selling Recyled Fashion: Acceptance of Upcycled Secondhand Clothes by Female consumers Age 25 to 65. North Dakota State University.

Jambeck, J. (2015). Plastic Waste inputs from Land into the Ocean. Siencemaf.org, Vol 347 ISSUE 6223 (13 February 2015)

Wang, Y. L \& Su, X. (2013). The New Concept of Green Design based on 'Low Carbon Life". Packaging Engineering, 35 (12), 87-90 . 
Kirchherr, J., Reike, D. and Hekkert, M. (2017). Conceptualizing the Circular Economyt: An analysis of 114 Definitions. januari 2017. SSRN Electronic Journal 127

Ginting, R. (2010). Perancangan Produk. Publiser graha Ilmu, 2010. ISBN 979756567X, 9789797565671

Syahni, D. (2019). Daur Ulang Sampah Plastik di Indonesia Rendah. http://www.mongabay.co.id , 10 September 2019
Sung, K. (2015). A Review on Upcycling: Current body of literature, knowlegde gaps and a way forward. In $17^{\text {th }}$ International Conference on Environmental, Culture, Economy and social Sustainablity (Vol. 17 No. 4, pp 28-40. Vinice. 